Attadrib: Jurnal Pendidikan Guru Madrasah Ibtidaiyah

(p-ISSN: 2599-3194 | e-ISSN: 2775-8109

Volume 4, Issue. 1, 2021, pp. 13-24

\title{
Pengaruh Motivasi Guru Terhadap Hasil Belajar Matematika Materi Pecahan Pada Siswa Kelas IV Ssekolah Dasar Inpres 109 Perumnas Kota Sorong
}

\author{
Yakobus Bwarnirun $^{1}$, Budi Santoso ${ }^{2}$ \\ ${ }^{1}$ Sekolah Dasar Inpres 109 Perumnas, Sorong Indonesia \\ ${ }^{2}$ Universitas Pendidikan Muhammadiyah Sorong, Indonesia \\ e-mail: yakobusbwarnirun105@gmail.com,92budisantoso@gmail.com
}

Submitted: 14-02-2021 Revised : 20-03-2021_Accepted: 21-04-2021

\begin{abstract}
This study aims to determine the effect of teacher motivation on mathematics learning outcomes in fractional material in class IV SD Inpres 109 Perumnas Sorong City. This research is an experimental study using a pretest-posttest group design research design. The independent variable in this study is teacher motivation while the dependent variable is learning outcomes. The sample of this study was the 50th grade students of SD Inpres 109 Perumnas Sorong City as many as 50 students, divided into two groups namely the Experimental Group with 25 students and the Control Group with 25 students. Data collection techniques used were questionnaire, test, observation and documentation. The data analysis technique consists of three stages, namely the stage of description of the data, the stage of testing the requirements of the analysis and the stage of testing the bypothesis. Questionnaire reliability test results obtained Cronbach's Alpha results of 0.860 . Then the reliability test results of the pre-test results obtained Cronbach's Alpha results of 0.750 and the reliability test of the post-test questions obtained Cronbach's Alpha results of 1.258. From the analysis of the results of the calculation of the motivation of learning experimental class students obtained a total score of 1787 with an average of 3.574 . Percentage of $64 \%$ shows good motivation from students and $36 \%$ shows quite good category. Whereas the control class obtained a total score of 1748 with an average of 3.496. Percentage of 64\% shows good motivation from students and 36\% shows quite good category. From the data analysis, the Kolmogrov Smirnov Asymp normality test was obtained. Sig (2-tailed) $>0.05$ then normal data is obtained. From the analysis of the data obtained homogeneity test that Asymp. Sig (2-tailed) > 0.05 then obtained homogeneous data. Paired T-test results obtained the t value of the experimental class $t$ count of 14.334 while the $t$ class of the control class of 14.511 and the value of $t$ count $>t$ table or sig $0.000<0.05$ in both classes then $H 1$ is accepted and HO is rejected. So it can be concluded that there is an influence of teacher motivation on learning outcomes of fraction material mathematics in class IV SD Inpres 109 Perumnas Sorong City, if the teacher's negative expectations decrease, the learning achievement of students will increase.
\end{abstract}

Keywords: Teacher Motivastion, Learning Outcomes, Mathematics

ABSTAK. Penelitian ini bertujuan untuk mengetahui pengaruh motivasi guru terhadap hasil belajar matematika materi pecahan pada siswa kelas IV SD Inpres 109 Perumnas Kota Sorong. Penelitian ini merupakan penelitian eksperimen dengan menggunakan desain penelitian pretestposttest group design. Variabel bebas dalam penelitian ini adalah motivasi guru sedangkan variabel terikatnya adalah hasil belajar. Sampel penelitian ini adalah siswa kelas IV SD Inpres 109 Perumnas Kota Sorong sebanyak 50 siswa, dengan dibagi menjadi dua kelompok yaitu Kelompok Eksperimen sebanyak 25 siswa dan Kelompok Kontrol sebanyak 25 siswa. Teknik pengumpulan data yang digunakan adalah angket, tes, observasi dan dokumentasi. Teknik analisis data terdiri atas tiga tahap, yaitu tahap deskripsi data, tahap uji persyaratan analisis dan tahap pengujian hipotesis. Hasil uji reliabilitas angket diperoleh hasil Cronbach's Alpha sebesar 0,860. Hasil uji reliabilitas soal pre test diperoleh hasil Cronbach's Alpha sebesar 0,750 dan uji reliabilitas soal post test diperoleh hasil Cronbach's Alpha sebesar 1,258. Analisis hasil perhitungan motivasi belajar siswa kelas eksperimen diperoleh skor total 1787 dengan rata-rata sebeesar 3,574. Persentase sebesar 64\% menunjukan motivasi baik dari siswa dan 36\% menunjukan kategori cukup baik. Sedangkan untuk 
kelas kontrol diperoleh skor total 1748 dengan rata-rata sebesar 3,496. Persentase sebesar 64\% menunjukan motivasi baik dari siswa dan 36\% menunjukan kategori cukup baik. Analisis data diperoleh uji normalitas kolmogrov smirnov Asymp. Sig (2-tailed) > 0,05 maka diperoleh data normal. Dari analisis data diperoleh uji homogenitas bahwa Asymp. Sig (2-tailed) > 0,05 maka diperoleh data homogen. Hasil uji Paired T-test diperoleh nilai t hitung kelas eksperimen sebesar 14,343 sedangkan thitung kelas kontrol sebesar 14,511 dan nilai t hitung $>\mathrm{t}$ tabel atau sig $0,000<$ 0,05 pada kedua kelas maka H1 diterima dan H0 ditolak. Disimpulkan bahwa ada pengaruh motivasi guru terhadap hasil belajar matematika materi pecahan pada siswa kelas IV SD Inpres 109 Perumnas Kota Sorong.

Kata Kunci: Motivasi Guru, Hasil Belajar, Matematika

How to Cite Bwarnirun, Y., \& Santoso, B. (2021). Pengaruh Motivasi Guru Terhadap Hasil Belajar Matematika Materi Pecahan Pada Siswa Kelas IV Ssekolah Dasar Inpres 109 Perumnas Kota Sorong. Attadrib: Jurnal Pendidikan Guru Madrasah Ibtidaiyah, 4(1), 13-24

\section{INTRODUCTION}

Motivasi belajar merupakan salah satu faktor yang menentukan keberhasilan siswa dalam kegiatan belajar, oleh karena itu siswa diharuskan memiliki motivasi belajar tersebut. Siswa yang memiliki motivasi belajar tinggi cenderung untuk selalu berusaha mencapai apa yang diinginkan walaupun mengalami hambatan dan kesulitan dalam merahinya(Nur Hakim \& Rahayu, 2019; Rofi'ah, 2020).

Motivasi dianggap penting dalam upaya belajar dan pembelajaran karena mendorong timbulnya tingkah laku dan mempengaruhi serta mengubah tingkah laku siswa. Di samping itu motivasi belajar memegang peranan penting dalam memberikan gairah atau semangat dalam belajar, sehingga siswa yang bermotivasi kuat memiliki energi banyak untuk melakukan kegiatan belajar. Peran guru dalam memberikan motivasi sangatlah penting pada proses pembelajaran karena menggerakan motivasi pada siswa dan menjadikan siswa itu lebih giat dan rajin bejalar (Muslimin \& Kartiko, 2020; Sj et al., 2021).

Belajar merupakan suatu proses usaha yang dilakukan seseorang untuk memperoleh suatu perubahan tingkah laku yang baru secara keseluruhan sebagai hasil pengalamannya sendiri dalam interaksi dengan lingkungannya, yang secara ideal harus mengacu pada tiga aspek yaitu kognitif (perubahan pengetahuan), psikomotorik (perubahan ketrampilan) dan afektif (perubahan nilai dan sikap). Setiap orang mempunyai pandangan yang berbeda tentang belajar, belajar merupakan suatu proses usaha yang dilakukan seseorang untuk memperoleh suatu perubahan tingkah laku (Pakpahan \& Habibah, 2021; Tajudin \& Aprilianto, 2020; Zuhriyah, 2020).

Guru memilki peran yang penting dalam proses belajar mengajar. Guru selalu terlibat dalam setiap proses belajar mengajar. Sebagai seorang pendidik, guru lebih banyak berhadapan dengan siswa selama proses belajar mengajar. Selain memberikan pengetahuan (transfer of knowledge) guru juga membimbing siswa, mendorong potensi siswa membangun kepribadian siswa, serta memberikan motivasi siswa dalam belajar. Oleh karena itu guru harus memilki kreativitas yang tinggi dalam menyampaikan materi pembelajaran dan memberikan motivasi agar siswa tertarik dan memperhatikan dalam kegiatan pembelajaran (Ma`arif \& Rusydi, 2020; Ma’arif, 2017a).

Matematika adalah salah satu mata pelajaran di sekolah tingkat sekolah dasar, dengan belajar matematika siswa dibiasakan untuk memperoleh pengalaman belajar. Tujuan pembelajaran matematika di sekolah dasar bahwa diberikannya pembelajaran matematika pada jenjang pendidikan dasar dan menengah meliputi: mempersiapkan siswa agar sanggup menghadapi perubahan keadaan kehidupan dan di dunia yang selalu berkembang, melalui latihan bertidak atas dasar pemikiran secara logis, rasional, kritis, cermat, jujur efektif dan efesien. Mempersiapkan siswa agar dapat menggunakan matematika dan pola pikir matematika dalam kehidupan seharihari, dan dalam mempelajari berbagai ilmu pendidikan. 
Pembelajaran matematika adalah suatu proses belajar mengajar yang dibangun oleh guru untuk mengembangkan kreativitas berpikir siswa yang dapat meningkatkan kemampuan berpikir siswa, serta dapat meningkatkan kemampuan mengkonstruksi pengetahuan baru sebagai upaya meningkatkan penguasaan yang baik terhadap materi matematika. Pembelajaran matematika bukan hanya mentranfer pengetahuan saja, akan tetapi peserta didik harus menjadi subjek dalam proses pembelajaran. Dalam pembelajaran matematika harus ada keterkaitan antara konsep yang satu dengan konsep yang lainnya, dan suatu penguasaan konsep menjadi prasyarat bagi konsep yang lainnya (Susanto, 2014: 186-187).

Berdasarkan hasil observasi yang telah dilakukan pada tanggal 18 September 2019 di SD Inpres 109 Kota Sorong kelas IV bertepatan dengan tempat magang III peneliti. Kondisi di Sekolah Dasar Inpres 109 Perumnas kota Sorong pada kelas IV, pelajaran matematika kurang diminati anak-anak bahkan matematika menurut mereka agak sulit khususnya materi pecahan. Berdasarkan pengamatan awal yang dilakukan peneliti, pada pelajaran matematika materi pecahan nampak masih banyak siswa yang kurang perhatian/fokus, jenuh, dan bosan saat proses pembelajaran matematika berlangsung ini dikarenakan guru sangat monoton dalam pembelajaran. Hal tersebut menyebabkan hasil belajar siswa rendah dibawah Kriteria Ketuntasan Minimal (KKM) mata pelajaran matematika 60. Dari keselurahan siswa kelas IV berjumlah 90 orang terdapat 68 siswa yang hasil belajarnya rendah dibawah 60 sedangkan 22 siswa saja yang hasil belajarnya diatas 60 .

Berdasarkan permasalahan tersebut maka motivasi sangat penting untuk mendorong siswa dalam belajar baik itu motivasi intrinsik maupun ekstrinsik. Bagi siswa yang mempunyai motivasi intrinsik kemauan belajarnya lebih kuat karena tidak tergantung pada faktor dari luar dirinya. Sedangkan bagi siswa yang tidak mempunyai motivasi intrinsik kemauan belajarnya tergantung pada faktor dari luar dirinya untuk belajar, karena ada rangsangan dari luar yang menyebabkan punya motivasi untuk belajar dan tugas gurulah untuk mengarahkan dan merubah agar siswa belajar bukan karena adanya faktor dari luar tetapi karena kebutuhan akan belajar sehingga hal itu bisa menjadi motivasi intrinsik.

Berdasarkan uraian latar belakang diataslah yang menjadi inspirasi dan dasar pemikiran peneliti untuk melakukan penelitian dengan judul Pengaruh Motivasi Guru Terhadap Hasil Belajar Matematika Materi Pecahan Pada Siswa Kelas IV SD Inpres 109 Perumnas Kota Sorong.

Berdasarkan rumusan latar belakang di atas, tujuan yang ingin dicapai dalam penelitian ini adalah untuk mengetahui pengaruh motivasi guru terhadap hasil belajar matematika materi pecahan pada siswa kelas IV SD Inpres 109 Perumnas Kota Sorong.

\section{KAAJIAN PUSTAKA}

\section{Pengertian Motivasi}

Motivasi adalah daya penggerak yang telah menjadi aktif. Motif menjadi aktif pada saat-saat tertentu, terutama bila kebutuhan untuk mencapai tujuan sangat dirasakan atau mendesak. Menurut Donald, motivasi adalah perubahan energi dalam diri seseorang yang ditandai dengan munculnya "Feeling" dan didahului dengan tanggapan terhadap adanya tujuan. (Sardiman, 2014) membahas pengertian motivasi tidak lepas dari kata "motif" itu sendiri. Motif adalah daya penggerak di dalam diri orang untuk melakukan aktivitas-aktivitas tertentu demi mencapai suatu tujun tertentu. berikut:

Donald dalam (Kompri, 2016:229) motivasi mengandung tiga elemen penting yaitu sebagi

Bahwa motivasi itu mengawali terjadinya perubahan energi pada diri setiap individu dalam sistem "neurophysiological" yang ada pada organisme manusia karena menyangkut perubahan energi manusia (walaupun motivasi itu muncul dari dalam diri manusia), penampakannya akan menyangkut kegiatan fisik manusia. 
Motivasi ditandai dengan munculnya, rasa atau "feeling", afeksi seseorang. Dalam hal ini motivasi relevan dengan persoalan-persoalan kejiwaan, afeksi dan energi yang dapat menentukan tingkah laku manusia.

Motivasi akan dirangsang karena adanya tujuan. Jadi motivasi dalam hal ini sebenarnya merupakan respons dari suatu aksi, yaitu tujuan. Motivasi memang muncul dari dalam diri manusia, tetapi kemunculannya karena terangsang atau terdorong oleh adanya unsur lain, dalam hal ini adalah tujuan. Tujuan ini akan menyangkut soal kebutuhan.

Motivasi belajar merupakan sesuatu keadaan yang terdapat pada diri seseorang individu dimana ada suatu dorongan untuk melakukan sesuatu guna mencapai tujuan. Menurut Mc Donald dalam Kompri (2016:229) motivasi adalah suatu perubahan energi di dalam pribadi seseorang yang ditandai dengan timbulnya afektif (perasaan) dan reaksi untuk mencapai tujuan. Dengan demikian munculnya motivasi ditandai dengan adanya perubahan energi dalam diri seseorang yang dapat disadari atau tidak. Menurut Woodwort (1995) dalam (Wina, 2006) bahwa suatu motive adalah suatu set yang dapat membuat individu melakukan kegiatan-kegiatan tertentu untuk mencapai tujuan. Dengan demikian motivasi adalah dorongan yang dapat menimbulkan perilaku tertentu yang terarah kepada pencapaian suatu tujuan tertentu. Perilaku atau tindakan yang ditunjukkan seseorang dalam upaya mencapai tujuan tertentu sangat tergantung dari motive yang dimiliknya. Sebagaimana yang diungkapkan oleh Arden (1957) dalam Wina Sanjaya (2010:250) bahwa kuat lemahnya atau semangat tidaknya usaha yang dilakukan seseorang untuk mencapai tujuan akan ditentukan oleh kuat lemahnya motive yang dimiliki orang tersebut.

Jenis- Jenis Motivasi dapat dilihat dari dua sudut pandang yakni motivasi intrinsik dan motivasi ektrinsik (Inganah, 2004). Motivasi Intrinsik yaitu motivasi yang berasal dari dalam diri pribadi individu. Motivasi Ekstrinsik yaitu motivasi dalam diri seseorang yang aktif atau berfungsi karena adanya rangsangan dari luar.

\section{Motivasi Guru}

Motivasi guru adalah motivasi yang timbul dari luar diri siswa yang merangsang siswa tersebut untuk belajar. Menurut Inganah, motivasi belajar siswa baik intrinsik maupun ekstrinsik dapat dikelola guru dan dihayati siswa sebagai berikut:

Guru adalah pendidik yang berperan dalam rekayasa pedagogis, menyusun desain pembelajaran dan melaksanakannya dalam proses belajar mengajar, menguasai komunikasi interaktif pembelajaran;

Siswa sebagai pelajar yang berkepentingan dalam menghayati belajar, memiliki motivasi intrinsik dan motivasi ekstrinsik;

Dalam pembelajaran guru melakukan tindakan mendidik dan memberi motivasi ekstrinsik melalui pemberian hadiah (reward), ganjaran, memuji, menegur, menghukum (punishment), atau memberi nasehat. Tindakan guru tersebut berarti menguatkan motivasi intrinsik dan mendorong motivasi ekstrinsik. Siswa tertarik belajar karena ingin memperoleh hadiah atau menghindari hukuman dan bertambah bersemangat untuk belajar (Ma'arif, 2017b; Ngalim, 2006; Surya, 2013).

Selanjutnya menurut (Winarsih, 2017)ada tiga fungsi motivasi yaitu:

Mendorong manusia untuk berbuat, jadi sebagai penggerak atau motor yang melepaskan energi. Motivasi dalam hal ini merupakan motor penggerak dari setiap kegiatan yang dilakukan.

Menentukan arah perbuatan kearah yang ingin dicapai. Dengan demikian motivasi dapat memberikan arah dan kegiatan yang harus dikerjakan sesuai dengan rumusan tujuannya.

Menyeleksi perbuatan, yakni menentukan perbuatan-perbuatan apa yang harus dikerjakan guna mencapai tujuan, jadi adanya motivasi akan memberikan dorongan, arah dan perbuatan yang akan dilakukan dalam upaya mencapai tujuan yang telah dirumuskan sebelumnya.

Fungsi motivasi sebagai pendorong usaha dalam mencapai prestasi, karena seseorang melakukan usaha harus mendorong keinginannya, dan menentukan arah perbuatannya kearah tujuan yang hendak dicapai. Dengan demikian siswa dapat menyeleksi perbuatan untuk menentukan apa yang harus dilakukan yang bermanfaat bagi tujuan yang hendak dicapainya. 


\section{Cara Menumbuhkan Motivasi Belajar}

Menurut (Hamzah B, 2011; Uno, 2008) indikator motivasi belajar meliputi: (a). Adanya hasrat dan keinginan berhasil; (b). Adanya dorongan dan kebutuhan dalam belajar; (c). Adanya harapan dan cita-cita masa depan. (d). Adanya penghargaan dalam belajar. (e). Adanya kegiatan yang menarik dalam belajar. (f). Adanya lingkungan belajar yang kondusif sehingga memungkinkan seseorang siswa dapat belajar lebih baik.

Dengan demikian dapat dikatakan bahwa indicator motivasi belajar adalah adanya dorongan baik dari luar maupun dari dalam diri siswa untuk mengadakan suatu perubahan tingkah laku dengan beberapa indikator yang mendukungnya. Dalam penelitian ini, motivasi belajar dapat diukur dengan menggunakan indikator motivasi belajar menurut Uno (2011) dengan enam indikator motivasi.

\section{Hasil Belajar}

Hasil belajar merupakan kemampuan-kemampuan yang ada pada siswa setelah melalui proses pembelajaran dimana hasil belajar tersebut dapat diketahui dengan melaksanakan penelitian baik dengan pengamatan langsung maupun dengan menggunakan tes. Hasil belajar menonjol sebagai terjadinya perubahan perilaku pada diri siswa, yang bisa diobservasi dan diukur dalam bentuk perubahan pengetahuan, sikap, dan keterampilan (Wardana, 2017).

Hasil belajar sebagai hasil dari perubahan tingkah laku berupa pengembangan kemampuan yang terdapat pada siswa setelah mengalami suatu kegiatan proses belajar. Selain itu hasil belajar digunakan sebagai bahan acuan untuk melihat sejauh mana kemampuan dan tingkat keberhasilan siswa dalam menguasai ilmu yang dipelajari sesuai dengan tujuan pembelajaran (Syamsu Hadi, 2014).

Berdasarkan pengertian di atas maka dapat disimpulkan bahwa hasil belajar adalah suatu penilaian akhir dari proses dan pengenalan yang telah dilakukan berkali-kali serta akan tersimpan dalam jangka waktu lama atau bahkan tidak akan hilang selama-lamanya.

\section{Penelitian Terdahulu}

Penelitian yang di lakukan oleh H.S. Bunyamin (2014) dengan judul penelitian yaitu Pengaruh Motivasi Guru Terhadap Prestasi Belajar Siswa Mata Pelajaraan IPS di SDN Rajagaluh Kidul Kecamatan Rajagaluh Kabupaten Majalengka.

Penelitian yang dilakukan oleh Maya Rahmatiya, Monawati. Monawati, Said Darnius (2017) dengan judul penelitian Pengaruh Pemberian Motivasi guru terhadap Hasil Belajar Matematika Siswa Kelas IV SD Negeri 20 Banda Aceh.

Penelitian yang dilakukan oleh Jumarniati (2011) dengan judul penelitian Pengaruh Motivasi Guru Terhadap Hasil Belajar Matematika Siswa Kelas X Sman Di Kecamatan Biringkanaya.

\section{METHOD}

Jenis penelitian ini adalah penelitian eksperimen dengan pendekatan kuantitatif. Desain pada penelitian ini adalah True Experimental. True Experimental adalah eksperimen betul-betul. Karena pada desain ini peneliti dapat mengontrol semua variabel yang mempengaruhi jalannya eksperimen. Jadi Dalam penelitan ini menggunakan desain Pretest-Posttest Control Group Design.

Variabel bebas di sini adalah pengaruh guru memberikan motivasi, sedangkan variabel terikat adalah hasil belajar matematika. Pengaruh guru memberikan motivasi dikatakan variabel bebas karena penyebab yang akan dilihat pengaruhnya terhadap hasil belajar dan hasil belajar dikatakan variabel terikat karena hasil belajar yang nantinya akan dicapai merupakan akibat dari guru memberikan motivasi. 
Dalam penelitian ini populasi adalah keseluruhan siswa kelas IV SD Inpres 109 Perumnas Kota Sorong berjumlah 90 orang siswa terdiri dari kelas A berjumlah 30, kelas B berjumlah 30, dan kelas $C$ berjumlah 30. Sampel yang dipakai oleh peneliti adalah 50 orang siswa kelas IV SD Inpres 109 Perumnas Kota Sorong untuk dijadikan kelas eksperimen dan kelas kontrol yang ditentukan dengan cara random. Jadi yang dipakai oleh peneliti adalah 25 siswa sebagai kelas eksperimen dan 25 siswa sebagai kelas kontrol. Adapun teknik pengumpulan data yang dipakai dalam penelitian ini adalah: (a). Kusioner (b). Tes; (c). Observasi; (d). Dokumentasi

Tahap Deskripsi Data

Langkah-langkah yang dipakai pada tahap deskripsi data ini adalah membuat rangkuman distribusi data pre test dan post test dari hasil statistik deskriptif program SPSS statistic for windows.

Uji Persyaratan Analisis

Uji Validitas

Validitas instrumen dilakukan dengan cara professional judgment yang artinya melalui satu dosen PGSD yang mengerti dan memahami serta meminta pertimbangan mengenai tes yang diberikan kepada siswa.

Uji Reliabilitas

Untuk lebih mempermudah reliabilitas instrumen, peneliti menggunakan bantuan SPSS statistic for windows.

Uji Normalitas

Uji normalitas bertujuan untuk menguji apakah dalam model regresi, variabel terikat dan variabel bebas keduanya mempunyai distribusi normal atau tidak. Data dinyatakan berditribusi normal jika nilai taraf signifikan lebih besar dari 0,05, dan untuk menguji apakah distribusi normal atau tidak dengan melakukan pengujian Kolmogorov Smirnov menggunakan SPSS statistic for windows.

\section{Uji Homogenitas}

Untuk mengetahui apakah data dalam variabel $\mathrm{X}$ dan $\mathrm{Y}$ bersifat homogen atau tidak. Kriteria yang digunakan dalam pengujian homogenitas ini yaitu, apabila nilai uji levene lebih kecil dari nilai tabel, atau nilai sig lebih besar dari 0,05 maka dapat dinyatakan bahwa populasi dalam kelompok bersifat homogen atau memiliki kesamaan, dan untuk uji ini menggunakan SPSS statistic for windows.

\section{Uji Hipotesis}

Penelitian ini digunakan untuk membandingkan rata-rata (mean) dari dua kelompok yaitu kelompok eksperimen dan kelompok kontrol. Dengan demikian, dapat diketahui perbedaan peningkatan hasil belajar antara kedua kelompok.

\section{HASIL DAN DISKUSI}

Uji Validitas

Penelitian ini menggunakan instrumen penelitian berupa tes berjumlah 25 butir soal pilihan ganda. Sebelum soal dan angket diberikan kepada siswa di sekolah, terlebih dahulu dikonsultasikan dengan dua professional Judgment 1 dosen PGSD, Alman, M.Pd. dan 1 dosen psikologi, Nengsih Sri Wahyuni, S.Sos., M.A. Unimuda Sorong dengan cara dimintai pendapat tentang instrumen tes yang telah disusun oleh peneliti. Ahli tersebut menyatakan bahwa instrumen tes dan angket yang telah dibuat tersebut telah layak digunakan. 
Uji Reliabilitas

Untuk menguji reliabilitas instrumen peneliti menggunakan SPSS. Berikut ini adalah hasil uji reliabilitas:

Tabel 4.3 Uji reliabilitas angket motivasi guru

Reliability Statistics

\begin{tabular}{|c|c|}
\hline Cronbach's Alpha & $\mathrm{N}$ of Items \\
\hline .846 & 20 \\
\hline
\end{tabular}

Berdasarkan perhitungan uji reliabilitas terhadap instrument angket motivasi guru dengan menggunakan SPSS diperoleh hasil Cronbach's Alpha sebesar 0,846. Dengan demikian, instrumen angket tersebut telah memenuhi syarat reliabel dengan tingkat reliabilitas tinggi.

Tabel 4.4 Uji reliabilitas soal pre test

Reliability Statistics

\begin{tabular}{|r|r|r|}
\hline & $\begin{array}{r}\text { Cronbach's } \\
\text { Alpha Based on } \\
\text { Cronb }\end{array}$ & $\begin{array}{c}\text { Standardized } \\
\text { Items }^{\mathrm{a}}\end{array}$ \\
\hline ach's Alpha $^{\mathrm{a}}$ & $\mathrm{N}$ of \\
\hline .750 & .711 & 20 \\
\hline
\end{tabular}

Berdasarkan perhitungan uji reliabilitas terhadap instrumen soal pre test dengan menggunakan program SPSS diperoleh hasil Cronbach's Alpha sebesar 0,750. Dengan demikian, instrumen soal Pre test tersebut telah memenuhi syarat reliabel.

Tabel 4.5 Uji reliabilitas soal post test

Reliability Statistics

\begin{tabular}{|r|r|r|}
\hline & $\begin{array}{r}\text { Cronbach } \\
\text { 's Alpha Based } \\
\text { Cronbac }_{\text {h's Alpha }} \text { on Standardized }^{\text {Items }}\end{array}$ & \multicolumn{2}{|c|}{$\begin{array}{c}\text { N of } \\
\text { Items }\end{array}$} \\
\hline .950 & .911 & 20 \\
\hline
\end{tabular}


Berdasarkan perhitungan uji reliabilitas terhadap instrumen soal post test dengan menggunakan program SPSS diperoleh hasil Cronbach's Alpha sebesar 0,950. Dengan demikian, instrumen soal post test tersebut telah memenuhi syarat reliabel.

Data Angket Motivasi Belajar Siswa Kelas Eksperimen dan Kontrol

Angket tersebut terdiri dari 20 butir pernyataan yang terdiri dari 10 pernyataan motivasi intrinsik dan 10 pernyataan motivasi ekstrinsik. Untuk mengukur tingkat keberhasilan motivasi siswa digunakan skor nilai dengan skala 1-4. Berdasarkan hasil penelitian deskripsi persentase untuk variabel motivasi belajar siswa kelas eksperimen diperoleh skor total 1787 dengan rata-rata sebeesar 3,574. Persentase sebesar 64\% menunjukan motivasi baik dari siswa dan 36\% menunjukan kategori cukup baik. Sedangkan untuk kelas kontrol diperoleh skor total 1748 dengan rata-rata sebesar 3,496. Persentase sebesar 64\% menunjukan motivasi baik dari siswa dan 36\% menunjukan kategori cukup baik. Hasil tersebut berdasarkan analisis deskriptif persentase pada lampiran motivasi belajar siswa termasuk kategori baik.

Uji Normalitas

Tabel 4.12 Rangkuman Hasil Uji Normalitas Pre Test

One-Sample Kolmogorov-Smirnov Test

\begin{tabular}{|ll|r|}
\hline & & $\begin{array}{r}\text { Unstandardi } \\
\text { zed Residual }\end{array}$ \\
\hline N & & 25 \\
& & .0000 \\
& & 000 \\
& Std. Deviation & 7.954 \\
Most Extreme & & 12579 \\
Differences & Absolute & .105 \\
& Positive & .102 \\
& Negative & -.105 \\
Kolmogorov-Smirnov Z & .523 \\
Asymp. Sig. (2-tailed) & .947 \\
\hline
\end{tabular}

Berdasarkan tabel di atas, terlihat bahwa data pre-test dan post-test hasil belajar kelas eksperimen memiliki nilai sig 0,947 > 0,05, maka dapat disimpulkan kelompok data tersebut berdistribusi normal.

Tabel 4.13 Rangkuman Hasil Uji Normalitas Post Test

One-Sample Kolmogorov-Smirnov Test

\begin{tabular}{|c|c|c|}
\hline & & $\begin{array}{l}\text { Unstandardized } \\
\text { Residual }\end{array}$ \\
\hline $\mathrm{N}$ & & 25 \\
\hline Normal Parameters ${ }^{a}$ & Mean & .0000000 \\
\hline
\end{tabular}




\begin{tabular}{|lc|r|} 
& Std. & \\
& Deviation & 3.24431598 \\
Most Extreme & Absolute & \\
Differences & Positive & .266 \\
& Negative & .266 \\
Kolmogorov-Smirnov Z & -.217 \\
Asymp. Sig. (2-tailed) & 1.331 \\
\hline
\end{tabular}

Berdasarkan tabel di atas, terlihat bahwa data pre-test dan post-test hasil belajar kelas kontrol memiliki nilai sig 0,058 >0,05, maka dapat disimpulkan kelompok data tersebut berdistribusi normal.

Uji Homogenitas

Tabel 4.14 Rangkuman Hasil Uji Homogenitas

\begin{tabular}{|l|r|r|r|}
\hline \multicolumn{1}{|c|}{$\begin{array}{r}\mathrm{K} \\
\text { elas }\end{array}$} & $\begin{array}{r}L \\
\text { evene }\end{array}$ & $\begin{array}{r}A \\
\text { symp } \\
\text { Sig } \\
(2- \\
\text { tailed })\end{array}$ & $\begin{array}{r}\text { Keter } \\
\text { angan }\end{array}$ \\
\hline $\begin{array}{r}P \\
\text { re-test }\end{array}$ & 020 & 0 & 0 \\
\hline$P$ & 2 & 0 & $\begin{array}{c}\text { Hom } \\
\text { ogen }\end{array}$ \\
\hline $\begin{array}{l}\text { ost- } \\
\text { test }\end{array}$ &, 398 &, 128 & $\begin{array}{c}\text { Hom } \\
\text { ogen }\end{array}$ \\
\hline
\end{tabular}

Hasil uji homogenitas variabel penelitian diketahui nilai levene pre-test 0,020 dengan nilai signifikan 0,888 sedangkan levene post-test 2.398 dengan signifikan 0,128. Dari hasil perhitungan hasil signifikan data pre-test ataupun post-test lebih besar dari 0,05 (sig $>0,05)$ maka dapat disimpulkan bahwa data dalam penelitian ini memiliki varians yang homogen.

\section{Uji Hipotesis}

Uji hipotesis dilakukan setelah semua data dari hasil penelitian terkumpul. Tujuan dari uji Paired T-test untuk menguji apakah motivasi guru terhadap hasil belajar matematika materi pecahan memiliki hasil belajar yang lebih baik terhadap hasil belajar siswa kelas IV SD Inpres 109 Perumnas Kota Sorong dibanding pembelajaran guru di sekolah selama ini. Secara teknis proses perhitungan dilakukan dengan bantuan program SPSS statistic for windows.

Berdasarkan hasil analisis uji Paired T-test menunjukkan bahwa nilai thitung dari pre testpost test kelas eksperimen sebesar 14.343 dan thitung dari pre test-post test kelas kontrol sebesar 14.511. Dari data tersebut terlihat nilai t hitung pada kelas eksperimen dan kontrol lebih besar dari t tabel sebesar 2.059, kemudian nilai sig $>0,05$ sehingga H1 diterima dan H0 ditolak. Artinya motivasi guru terhadap hasil belajar matematika materi pecahan memiliki hasil belajar yang lebih baik terhadap hasil belajar siswa kelas IV SD Inpres 109 Perumnas Kota Sorong dibanding pembelajaran guru di sekolah selama ini. Jadi dapat disimpulkan bahwa terdapat hasil yang lebih baik pada kelas eksperimen dengan motivasi guru terhadap hasil belajar matematika materi pecahan memiliki hasil belajar yang lebih baik terhadap hasil belajar siswa kelas IV SD Inpres 109 Perumnas Kota Sorong dibanding pembelajaran guru di sekolah selama ini. 


\section{Discussion}

Berdasarkan hasil penelitian yang dilakukan pada siswa kelas IV SD Inpres 109 Perumnas Kota Sorong tahun pelajaran 2019/2020 tentang "pengaruh motivasi guru terhadap hasil belajar matematika materi pecahan pada siswa kelas IV SD Inpres 109 Perumnas Kota Sorong" hasil penelitian modus post test, kelas eksperimen memperoleh nilai 90, sedangkan kelas kontrol memperoleh nilai 85. Mean post test kelas eksperimen 91,40, sedangkan kelas kontrol memperoleh nilai 87,20.

Tabel 4.17 Hasil Penelitian Modus dan Mean Pre Test-Post Test Kelompok Eksperimen dan Kontrol.

\begin{tabular}{llll}
\hline No & Hasil (Kelompok) & Modus & Mean \\
\hline $\mathbf{1}$ & Pre Test (eksperimen) & 70 & 63,60 \\
$\mathbf{2}$ & Pre Test (kontrol) & 60 & 63,40 \\
$\mathbf{3}$ & Post Test (eksperimen) & 90 & 91,40 \\
$\mathbf{4}$ & Post Test (kontrol) & 85 & 87,20 \\
\hline
\end{tabular}

Jika dilihat dari peningkatan mean pre test-post test antara kelas eksperimen dan kontrol, peningkatan mean pre test-post test kelas eksperimen sebesar 27,80, sedangkan kelas kontrol sebesar 23,80. Peningkatan mean pre test-post test antara kelas eksperimen dan kelas kontrol terdapat selisih 4,00. Peningkatan nilai t hitung dari pre test-post test kelas eksperimen sebesar 14,343 sedangkan t hitung dari pre test-post test kelas kontrol sebesar 14,511. Peningkatan nilai t hitung dari pre test-post test antara kelas eksperimen dan kelas kontrol terdapat selisih 168 (Singgih Santoso, 2014). Peneliti secara keseluruhan mengontrol semua variabel yang mempengaruhi penelitian. Variabel yang dapat dikontrol oleh peneliti adalah penentuan kelas eksperimen dan kelas kontrol dan jumlah treatment yang sama.

\section{KESIMPULAN}

Berdasarkan hasil uji reliabilitas angket diperoleh hasil Cronbach's Alpha sebesar 0,860. Kemudian hasil uji reliabilitas soal pre test diperoleh hasil Cronbach's Alpha sebesar 0,750 dan uji reliabilitas soal post test diperoleh hasil Cronbach's Alpha sebesar 1,258. Dari analisis hasil perhitungan motivasi belajar siswa kelas eksperimen diperoleh skor total 1787 dengan rata-rata sebeesar 3,574. Persentase sebesar 64\% menunjukan motivasi baik dari siswa dan 36\% menunjukan kategori cukup baik. Sedangkan untuk kelas kontrol diperoleh skor total 1748 dengan rata-rata sebesar 3,496. Persentase sebesar 64\% menunjukan motivasi baik dari siswa dan $36 \%$ menunjukan kategori cukup baik. Dari analisis data diperoleh uji normalitas kolmogrov smirnov Asymp. Sig (2-tailed) >0,05 maka diperoleh data normal. Dari analisis data diperoleh uji homogenitas bahwa Asymp. Sig (2-tailed) > 0,05 maka diperoleh data homogen. Hasil uji Paired T-test diperoleh nilai t hitung $>\mathrm{t}$ tabel dari kelas eksperimen sebesar 14,343 $>2,059$ sedangkan $\mathrm{t}$ hitung kelas kontrol sebesar 14,511 > 2,059 pada kedua kelas maka H1 diterima dan H0 ditolak. Sehingga dapat disimpulkan bahwa ada pengaruh motivasi guru terhadap hasil belajar matematika materi pecahan pada siswa kelas IV SD Inpres 109 Perumnas Kota Sorong.

\section{REFERENSI}

Hamzah B, U. (2011). Profesi Kependidikan, Problema, Solusi dan Reformasi di Indonesia. Bumi Aksara. 
Ma`arif, M. A., \& Rusydi, I. (2020). IMPLEMENTASI PENDIDIKAN HOLISTIK DI PONDOK PESANTREN AMANATUL UMMAH MOJOKERTO. EDUKASI: Jurnal Penelitian Pendidikan Agama Dan Keagamaan, 18(1), Article 1. https://doi.org/10.32729/edukasi.v18i1.598

Ma'arif, M. A. (2017a). Analisis Konsep Kompetensi Kepribadian Guru PAI menurut AzZarnuji. ISTAWA, 2(2), http://journal.umpo.ac.id/index.php/istawa/article/view/624

$35-60$.

Ma'arif, M. A. (2017b). Hukuman (punishment) Dalam Perspektif Pendidikan Di Pesantren. Ta'allum: Jurnal Pendidikan Islam, 5(1), 1-20. https://doi.org/10.21274/taalum.2017.5.1.120

Muslimin, T. A., \& Kartiko, A. (2020). Pengaruh Sarana dan Prasarana Terhadap Mutu Pendidikan di Madrasah Bertaraf Internasional Nurul Ummah Pacet Mojokerto. Munaddhomab: Jurnal Manajemen Pendidikan Islam, 1(2), 75-87. https://pasca.jurnalikhac.ac.id/index.php/munaddhomah/article/view/30

Ngalim, P. (2006). Ilmu Pendidikan Teoritis dan Praktis (17th ed.). Remaja Rosdakarya.

Nur Hakim, M., \& Rahayu, F. D. (2019). Pembelajaran Saintifik Berbasis Pengembangan Karakter. Nazhruna: Jurnal Pendidikan Islam, 2(1), 1-27. https://doi.org/10.31538/nzh.v2i1.148

Pakpahan, P. L., \& Habibah, U. (2021). Manajemen Program Pengembangan Kurikulum PAI dan Budi Pekerti dalam Pembentukan Karakter Religius Siswa: Management of IRE Curriculum Development Program and Character in Forming Student's Religious Character. Tafkir: Interdisciplinary Journal of Islamic Education, 2(1), 1-20. https://doi.org/10.31538/tijie.v2i1.19

Rofi'ah. (2020). Meningkatkan Motivasi Belajar Pendidikan Sejarah Kebudayaaan Islam Melalui Metode Pembelajaran Mind Mapping. Attadrib: Jurnal Pendidikan Guru Madrasah Ibtidaiyah, 3(2), 33-40. http://www.jurnal.staidagresik.ac.id/index.php/attadrib/article/view/109

Sj, D. S., Maarif, M. A., \& Zamroni, A. (2021). Strategi Pengembangan Program Pembelajaran Pendidikan Agama Islam Sekolah: The Development Strategy of Islamic Religious Education Learning Programs. Tafkir: Interdisciplinary Journal of Islamic Education, 2(1), 20 40. https://doi.org/10.31538/tijie.v2i1.21

Surya, M. (2013). Psikologi Guru, Konsep dan Aplikasi, dari Guru untuk Guru,. Alfabeta.

Tajudin, A., \& Aprilianto, A. (2020). Strategi Kepala Madrasah..dalam Membangun Budaya Religius Peserta Didik. Munaddhomab: Jurnal Manajemen Pendidikan Islam, 1(2), 101-110. https://pasca.jurnalikhac.ac.id/index.php/munaddhomah/article/view/34

Uno, H. B. (2008). Teori Motivasi \& Pengukurannya: Kajian \& Analisis Di Bidang Pendidikan.

Wina, S. (2006). Strategi Pembelajaran: Berorientasi Standar Psoses Pendidikan (11th ed.). Kencana Prenada Media Group.

Winarsih, S. (2017). Kebijakan dan Implementasi Manajemen Pendidikan Tinggi dalam Meningkatkan Mutu Pendidikan. Cendekia: Jurnal Kependidikan Dan Kemasyarakatan, 15(2), 51-66. https://doi.org/10.21154/cendekia.v15i2.1005

Zuhriyah, A. (2020). Pengembangan Media Pembelajaran Permainan Ular Tangga Untuk Meningkatkan Motivasi Belajar Siswa dan Hasil Belajar IPS di Madrasah Ibtidaiyah. Attadrib: Jurnal Pendidikan Guru Madrasah Ibtidaiyah, 3(2), 26-32. http://www.jurnal.staidagresik.ac.id/index.php/attadrib/article/view/110

Kompri. (2016). Motivasi Pembelajaran Perspektif Guru dan Siswa. Bandung: PT Rosda Karya.

Maya Rahmatiya. (2017). Pengaruh Media E-learning Terhadap Hasil Belajar Matematika Siswa Kelas IV SD Negeri 20 Banda Aceh, Jurnal Ilmiah Pendidikan Guru Sekolah Dasar FKIP Unsyiah Volume 2 Nomor 1, 21-47.

"Makalah Pengaruh Minat dan Motivasi Belajar Terhadap Prestasi Belajar dalam Pelajaran Matematika di MA AL Fattah Sumbermulyo." http://www.academia.edu (akses 15 Februari 2020). 
Sardiman, A.M. (2011). Psikologi Pendidikan Edisi II. Jakarta: Kencana Prenada Media Group.

Sardiman, A.M. (2010). Interaksi dan Motivasi Belajar Mengajar. Jakarta: Raja Grafindo Persada, hlm.221.

Sardirman, A.M. (2014). Interaksi dan Motivasi Belajar Mengajar. Jakarta: Rajawali Pers.

Santoso, Singgih. (2014). Statistik Parametrik Edisi Revisi. Jakarta: Elex Media. Komputindo.

Susanto, Ahmad. (2014). Teori Belajar Pembelajaran di Sekolah Dasar. Jakarta: Persada Media Group.

Sudjana, N. (2010). Penilaian Hasil Proses Belajar Mengajar. Bandung: PT Remaja Rosdakarya.

Sugiyono. (2011). Metode Penelitian Pendidikan. Bandung: Alfabeta.

Sugiyono. (2013). Metode Penelitian Kuantitatif Kualitatif dan RND. Bandung: Alfabeta.

Sjukur, S. B., Negeri, S. M. K., Kab, S., \& Bumbu, T. (n.d.). Dan Hasil Belajar Siswa Tingkat Smk The Effects Of Blended Learning On The Learning Abstract: The Effects of Blended Learning on the Learning Motivation and Achievement Students in, 2(November 2012), Jurnal Pendidikan, 368-378.

Syamsu, Hadi. (2014). Economic Education, Analysis Journal, 3(2), 359-365.

Uno, B. Hamzah. 2016. Teori Motivasi Dan Pengukurannya Analisis di Bidang Pendidikan. Jakarta: P'T Bumi Aksara 